\title{
ARCHITECTURE, SPACE AND IDEOLOGY: BETWEEN ADORNO AND LEFEBVRE
}

\section{A B S T R A C T}

Can architecture become a site of resistance to the machinery of estrangement and alienation? The German philosopher Theodor Adorno found art, where he included specific forms of architecture, to be the only exit from the dominance of machinery of the total system. If architecture in Adorno's philosophy could, with its negative position, step behind the screens into an autonomous art, the French philosopher and sociologist, Henri Lefebvre, developed a more radical notion: the distinctive scenery of architecture, everyday life, is intensely subjected to alienation. As much as Lefebvre puts focus on abstract and social space as a specific production of social relations, he also argued that every architecture is a priori ideological.

Introducing the status architecture was given by Adorno and Lefebvre in the age of the birth of neoliberalism, thus paralleling the concepts of cultural industries with arts, social with abstract space, the paper outlines the basic entry point of two distinctive representatives of Neo-Marxism into architecture, in order to suggest an epistemology of architecture, which starts at a foremost critical point.

\footnotetext{
Mateja Kurir

Centre for Advanced Studies, University of Rijeka

mateja.kurir@gmail.com
}

KEY WORDS

ARCHITECTURE

CRITICAL THEORY

THEODOR ADORNO

HENRI LEFEBVRE

IDEOLOGY 


\section{ARCHITECTURE WITHIN CRITICAL THEORY:} WITH OR WITHOUT IDEOLOGY

Architecture mainly finds its place in philosophy as an ideological power. Almost every important philosopher of the twentieth century wrote at least one essay concerning architecture and it does not come as a surprise that most of them were dealing with ideology: Walter Benjamin, Theodor W. Adorno, Henri Lefebvre, Fredric Jameson are just some of the most distinguished names of such an entry point into architecture. This entry point was also declared in a cohesive statement by Italian architect Aldo Rossi who saw architecture as a hegemonic work, which could be read as a dominance of ideology: "There are no buildings of opposition, because the architecture that is going to be realised is always an expression of the dominant class." If architecture is always an expression of the dominant class, i.e. a spatial manifestation of its ideology, what would be the entry point to reflect on architecture, which would still leave space to a coherent epistemology ${ }^{2}$ of architecture?

The concept of ideology was elaborated in length by critical theory, which is usually associated with the Frankfurt School and its influence. In a specific sense, one could say ideology was first coined by Plato with his concept of ideas, that could be read as the first ideo-logy, ${ }^{3}$ but today the term is generally referred to as a misconception. Karl Marx defined ideology in The German Ideology (1846) in a more exact way, as a specific "camera obscura": "...the camera obscura that gives us an inverted picture of the world, so that ideas and not material processes come to be seen as the determining factors." ${ }^{\prime 4}$ Adorno was one of the prominent leaders of the Frankfurt School who continued to argue in the direction of this position: as the central focus of his work was aesthetics, he intrinsically associated everything from the cultural realm through to architecture, with ideology.

With this paper, which is certainly just an outline of ideas giving the vast, multi-layered and complex nature of issues at hand, I would like to (re)open the reflection on architecture from a critical perspective, thus provide some formulas to reflect on the intersection of architecture, space and ideology. While trying to explain the basic position of Adorno and Lefebvre on this notion, I will attempt to answer the following question: Do contemporary space and architecture alienate to the point that we are so accustomed to this estrangement we cannot see behind the scenes of machinery anymore? This question is, in a way, a rhetorical one and has been present in philosophy, especially the one with a materialistic background, hence in architectural discourse prominent in the second half of the twentieth century. ${ }^{5}$ Can we find an answer? 
ADORNO ON ARCHITECTURE:

ART OPPOSING CULTURAL INDUSTRIES OF TOTAL SYSTEM

Adorno's perception of art, cultural industries and architecture can be an extremely fertile ground for a contemporary reception of architecture because of its insistence on the negative, especially on the negative side of progress.

Since Adorno's fundamental statement was the negative side of progress and reason, which is embodied in the concept of the negative dialectics of the Enlightenment, we can take his take on architecture to be almost as a pioneering critique of the twentieth century. In his main works, Dialectic of Enlightenment (1944, with Max Horkheimer) and The Negative Dialectics (1966), Adorno questioned the contradictory, the flip side of the "apparent" progress, which is related with reason overcoming myth during the Enlightenment period of bourgeois revolution. For Adorno, the aim of the Enlightenment was to make everything reasonable, to dominate fear stemming from myths with science. Within the Age of Enlightenment science emerges as a new master and mathematics with its complete abstraction at its best manifestation. Adorno (and Horkheimer) looked at the flip side of progress, liberation and other ideologically-connected terms of the Enlightenment in order to identify the source of fascism and totalitarianism. The conclusion of their efforts, to put it simply, was that this project was a failure because it became its own ideology, which is now leading the world.

The negative side of development, reason, of science taking over religion and all previously established beliefs, also shaped Adorno's view on architecture and his concept of modern living. For Adorno, modern living was immanently crossed out, prevented and impossible. Here, modern living was placed within capitalism, i.e. within the inescapable "total system" of the Western society that was characterised by the "seamless web of media technology, multinational corporations, and international bureaucratic control". One of the founding elements of the total system are cultural industries, as films and all other forms of mass distraction, which Adorno placed on the other side of art. He found art, where he included also some specific - not all - forms of architecture, to be the only possible exit from the dominance of machinery of the total system of development. We can interpret his statement "art is the negative knowledge of the actual world"6 precisely within this context. Adorno's definition of the essence of the work of art is remarkably long-sighted: “.... a successful work... is not one which resolves objective contradictions in a spurious harmony, but one which expresses the idea of harmony negatively by embodying the contradictions pure and uncompromised." ${ }^{.7}$ According to him, this urge embodied contradictions 
in "true" architecture. The works of Franz Kafka, Samuel Beckett and Arnold Schonberg, among others, were art in Adorno's view, precisely because of „their intransigent refusal of any form of reconciliation." If cultural industries are the ones who support the total system, art should expose its contradictions.

The opening lines of Adorno's Minima Moralia (1944) are quite disturbing: life is reduced to consumption only, the only way to come beyond this estranged form is to analyse the objective powers that are determining the individual existence. Adorno stressed here that it is impossible to understand an individual phenomenon without grasping the whole, where ideology has a key role: „Our perspective of life has passed into an ideology which conceals the fact that there is life no longer." Adorno contemplated on the intersection between life and cultural ideology as a prominent feature, which was essential for the Frankfurt School and, for him, reduced to a complete lie. In this position, where life is reduced to ideology, where "world is systematised horror" 10 and where culture is just a false manifestation, a lie, meant to hide the true relations within society, architecture works within the system: "The predicament of private life today is shown by its arena. Dwelling, in the proper sense, is now impossible."11 His view on modernist architecture, that was mostly known for its aesthetic functionalism, especially in Germany, is extremely negative.

"The functional modern habitations designed from a tabula rasa, are living-cases manufactured by experts for philistines, or factory sites that have strayed into the consumption sphere, devoid of all relation to the occupant: $[\ldots]^{\prime \prime 12}$

Architecture, in its modern manifestation, is reduced to just boxes, to cases for philistines. A house in Minima Moralia does not have a meaning any more, just as the home does not exist any longer. Also architecture is not possible, as living in the era of fascism and of a total system (in the Western world) were not possible at all. Architecture is just one of the notions of ideology, it simply gives a façade to the culture as ideology and works within the dialectics of the Enlightenment. Within the concept where everything is ideology, where culture exists as a lie, it seems that architecture only has an ideological function.

Adorno broadened this position in the essay Functionalism Today (1965), where the opposition to Adolf Loos and his fight against the ornament (al) in architecture was at the forefront. For Adorno, Loos conceives the ornament from a distinctive "bourgeois works ethics" perception, whereby the ornament is repulsive precisely because it does not have a purpose. This is also the perspective of the total system, which wants to cut off every enjoyment. 
Adorno saw Loos's rejection of style and the fight against the ornament (al) that was intrinsic to functional architecture in its contradiction, and wrote: "The absolute rejection of a style becomes style." ${ }^{13}$ For Adorno, the key attribute of architecture, that would be able to surpass the ideological notion of the dialectic of the Enlightenment, is for it to work as an autonomous art. He is striving for architecture which would be able to open the uncompromised contradictions of the society: "Architecture contradicts the needs of the here and now as soon as it proceeds to serve those needs - without simultaneously representing any absolute or lasting ideology."14

Architecture in this realm should be able to combine its two extremes: the formal construction and its function. In this approach, Adorno introduces a distinction between "true" architecture and other buildings / interventions in space, which are part of machinery, as works of ideology. In making those distinctions within architecture, he is putting forward a practical proposition in order to look beyond the (mis)conception on how art / architecture can present the truth.

\section{THE POWER OF IDEOLOGY IN HENRI LEFEBVRE'S CONCEPT OF EVERYDAY LIFE AND ABSTRACT SPACE}

Taking Henri Lefebvre's notion of the distinctive scenery of architecture, everyday life, and his theory of the abstract space, we can expand on the possibility of a critical materialistic epistemology of architecture. In order to present an interconnection between alienation, space, architecture and ideology, I am proposing some formulas to underline the key ideas of two of Lefebvre's central books - The Critique of Everyday Live (1947-1981) and The Production of Space (1974).

Lefebvre recalled everyday life as a forgotten and neglected entity within theory. His main aim in The Critique of Everyday Live is to put everyday life on the stand again because, only at this level, a revolution and change in society can occur. It is important to underline that for Lefebvre it is this basic scenery of architecture, everyday life, which is intensely subjected to alienation: "elements of everyday life (work-family and 'private' life- leisure activities) implies an alienation." ${ }^{\prime 15}$ Although we perceive our everyday life as familiar it does not mean that we actually understand it. For him, alienation works precisely at the core of privacy of an individual's everyday life. Alienation is also the predominant feature of the post-war social capitalist system; in a nutshell, it is the best explanation for all the contradictions and tensions in 
society. For Lefebvre, the wholeness of work, leisure activities, family life and privacy creates a global structure, the totality of conditions, where life is at most colonised by capitalism. At the spatial level, architecture, cities, markets and other spatial elements, have an a priori ideological determination as they are marked by the alienated everyday life.

Lefebvre also proposed a critical notion of the dominance of the system on space in his main work The Production of Space (1974). The central argument of the book is that space is not a neutral container. The French Marxist is primarily concerned with the social connotation of space, which can be traced at the beginning of his book concerning the question: "In which way social relations exists?". Lefebvre introduces the concept of the social space in order to answer this question, and he defines it as "social space is a social product." Lefebvre coined a variety of different types of spaces, among them those that are abstract, social, real, ideal, absolute and historical spaces. What defines a social space, is that it is an explicit space, created as a derivate of specific modes of production of a society. It contains social relations of reproduction and production modes, which differ from society to society. Social space is for Lefebvre the outcome of a multitude of reigning efforts; it cannot be an empty, neutral container.

Going further, Lefebvre wrote that space is produced, not simply given: "The production of space is a process." Since space is produced, Lefebvre proposed to shift the focus of reflection from space to the social production of space, which is crucial for the reproduction of society and capitalism itself. At this point, Lefebvre introduced the importance of understanding of abstract space: "Capitalism and neo-capitalism have produced abstract space." For Lefebvre the abstract space is the space for goods, money and the state created by the bourgeoisie. The abstract space dominates our perspective on space and presents, on an abstract level, an ideology in a spatial formation. For Lefebvre, abstract space is thus the one where a contemporary city has exploded.

The background of The Production of Space, as almost in every Lefebvre's book, is a formulation of a political programme for the interruption of the existing relations of domination. This political programme remains hidden until the very end of the book, when Lefebvre concluded: "Life can only be changed by the production of space." This call for a radical twist, for a revolution, screams out from a space as a social paradigm, together with an urge for change in architecture, which is built into space with this kind of a forceful ideological connotation. 


\section{CRITICAL EPISTEMOLOGY OF ARCHITECTURE}

Adorno and Lefebvre emphasised the dominant connection architecture has with capitalism, with the total system of a contemporary society and its ideology. In doing so, they looked at the impact of architecture, the modes of its production and productive forces that are obliging its production. If a critical materialistic epistemology of architecture exists and if this epistemology could be extracted from Adorno's and Lefebvre's work, it would be focusing on the result of architecture and its social, economic and political impact. This kind of epistemology would look beyond the fashionable names and adjectives of any architecture, it would dive into the whole surrounding environment, the productive modes and the impact this kind of architecture has on society. In this way, it would enable a look behind the scenery of machinery of the total system. This would also mean that if a building (or other architectural work) does not condense the urgent oppositions of a society, would not be called architecture, but simply ideology in a spatial manifestation.

The centre and the periphery, gated communities and slums, shopping malls and airports, residential and business buildings: they are all condensed cases of the alienating force of space and architecture of the contemporary world. A critical epistemology of architecture could enable a possible dissolution of this ideology, which is working towards a dominant spatial estrangement. 
Aldo Rossi in Pier Vittorio Aureli, The Project of Autonomy. Politics and Architecture within and against Capitalism (New York: Princeton Architectural Press, 2008), 68.

I understand epistemology as a core area of philosophy, which is concerned with "nature, sources and limits of knowledge" as defined in: The Shorter Routledge Encyclopedia of Philosophy, (London: Routledge, 2005).

More on this: Sven-Olov Wallenstein, Architecture, Critique, Ideology (Stockholm: Axl Books, 2016), xvii.

In the introduction to the collection of essays Architecture, Criticism, Ideology (ed. Joan Ockman, 1997), we can read Fredric Jameson's question of the intertwined relation between architecture, ideology, values and utopia: "How is it possible for a cultural text that fulfils a demonstrably ideological function, as a hegemonic work whose formal categories as well as its content secure the legitimation of this or that form of class domination - how is it possible for such a text to embody a properly utopian impulse, or to resonate a universal value inconsistent with the narrower limits of class privilege that inform its more immediate ideological vocation?" Fredric Jameson, "The Political Unconscious," in Joan Ockman (ed.) Architecture, Criticism, Ideology (New York: Princeton Architectural Press, 1985), 11. 
Theodor Adorno, Aesthetics and Politics (London, New York: Verso, 1997), 146.

Theodor Adorno, Prisms (London: Neville Spearman, 1967), 32.

Presentation - Adorno, in: Aesthetics and Politics (London, New York: Verso, 1997), 146.

Theodor W. Adorno, Minima Moralia: Reflections on a damaged life (London, New York: Verso, 2005), 15.

Ibid, 113.

Ibid, 38.

Ibid, 38 .

Theodor Adorno, Functionalism Today (London: New York: Routledge, 1997), 10.

Ibid, 15 .

Henri Lefebvre, Critique of Everyday Life (New York: Verso, 2014), 54. 
Adorno, Theodor. Minima Moralia, reflection on a damaged life. London: New York: Verso, 2005.

Adorno; Theodor. Functionalism Today, in: Leach, Neil (ed), Rethinking Architecture. A reader in Cultural Theory. London: New York: Routledge, 1997.

Adorno, Theodor. Aesthetics and Politics. London, New York: Verso, 1997.

Adorno, Theodor. Prisms. London: Neville Spearman, 1967.

Aureli, Pier Vittorio. The Project of Autonomy. Politics and Architecture within and against Capitalism. Princeton Architectural Press: New York, 2008.

Benjamin, Andrew and Rice, Charles. Walter Benjamin and the architecture of modernity. Victoria: re-press, 2009.

Benjamin, Walter. The Arkades Project. Cambridge (MA): Harvard University Press, 2002.

Ockman, Joan (ed). Architecture, Criticism, Ideology. Princeton Architectural Press: New York, 1985.

Lefebvre, Henri. Critique of Everyday Life. The One-Volume Edition, London: New York: Verso, 2014.

Lefebvre, Henri. Produkcija prostora. Studia Humanitatis: Ljubljana, 2013.

Jameson, Fredric. Architecture and the critique of ideology, in: Architecture, Cirticism, Ideology, ed. By Joan Ockman, New York: Princeton Architectural Press, 1985.

Rotar, Braco. Pomeni prostora. Ideologije v urbanizmu in arhitekturi. Ljubljana: Delavska enotnost, 1981.

Tafuri, Manfredo. Progetto e utopia, Architettura e sviluppo capitalistico. Rome: Biblioteca Universale Laterza, 1973.

Wallenstein, Sven-Olov. Architecture, Critique, Ideology: Writings on Architecture and Theory. Stocholm: Axl Books, 2016. 